\title{
Evaluation of temperature-based Penman-Monteith (TPM) model under the humid environment
}

\author{
P. K. Pandey ${ }^{1}$ - Vanita Pandey ${ }^{2}$
}

Received: 24 July 2016/ Accepted: 26 July 2016/Published online: 9 August 2016

(C) Springer International Publishing Switzerland 2016

\begin{abstract}
In this study, an attempt is made to check the suitability of TPM approach and present software to estimate reference evapotranspiration based on TPM and Hargreaves-Samani (HS) method by using Visual Basic Environment. Considering the FAO-56 Penman-Monteith (FAOPM) as the standard model, the comparative performances of selected methods were evaluated under the climatic condition of Umaim, Meghalaya, India. Using the Root Mean Square Error (RMSE)' and 'correlation coefficient (r)' as statistical measures of 'goodness-of-fit' the regression analysis was carried out. Based on the regression analysis TPM (RMSE $=0.014 \mathrm{~mm} \mathrm{day}^{-1}, \mathrm{r}=0.92$ ) was found better followed by HS (RMSE $=0.054 \mathrm{~mm}$ day $^{-1}$, $r=0.87$ ). The average overestimate (e.g. $1.97 \%$ ) by TPM were found to be in close agreement with the FAOPM. These results support the use of the TPM approach under limiting climatic data conditions for Umaim.
\end{abstract}

Keywords Software - Temperature-based PenmanMonteith (TPM) · HS method

P. K. Pandey

pkpnerist@gmail.com

1 Department of Agricultural Engineering, North Eastern Regional Institute of Science and Technology, Nirjuli, Itanagar, Arunachal Pradesh, India

2 Department of Soil and Water Engineering, College of Agricultural Engineering and Post-Harvest Technology, Ranipool, Gangtok, Sikkim, India

\section{Introduction}

Reference evapotranspiration $\left(\mathrm{ET}_{0}\right)$ is the most important index to represent evaporative demand of the atmosphere. It has a vital role in FAO recommended two-step approach of estimation of actual crop evapotranspiration (Pandey et al. 2016; Pandey and Pandey 2011). The FAO56 Penman-Montieth method (FAOPM) is the FAO and American Society of Civil Engineers (ASCE) Task Committee on Standardized Evapotranspiration Calculations (ASCE-Environmental and Water Resources Institute (EWRI), 2005) (ASCE-EWRI 2005) accepted and sole recommended method for reliable estimation of $\mathrm{ET}_{0}$ in absence of directly lysimetric measured values (Pandey et al. 2014; 2016) but, its practical applicability in limited in many parts of world, because of non-availability of its least required input climatic limits mainly solar radiation and wind speed. There are many alternative approaches based on different input need are in practice to the estimation of $\mathrm{ET}_{0}$ in a situation of non-applicability of FAOPM model. Among the various approaches, the temperature-based $\mathrm{ET}_{0}$ models are the easiest and primary methods for estimating $\mathrm{ET}_{0}(\mathrm{Xu}$ and Singh 2002). According to Jensen et al. (1990), the temperature is the sole input of $\mathrm{ET}_{0}$ process. These methods of estimating $\mathrm{ET}_{0}$ are widely used because, the air temperature data are more readily available in most of the meteorological stations compared to other weather data such as solar radiation, sunshine hours; relative humidity and wind speeds that are required by models of the other groups. Moreover, in places where the data for other weather variables exist; they are always with a broad range of missing data, making the computation of daily $\mathrm{ET}_{0}$ with those models difficult.

The main shortcoming of FAOPM equation is that it requires various weather data that are not always available 
for many locations (Droogers and Allen 2002). Additionally, computation procedure of missing variable is required exhaustive computation procedure. This limitation needs to be addressed especially in the limited data condition.

To discuss this issue, Allen et al. (1998) prescribed strategies to assess the limits of the FAOPM when the some of the climate variable are absent. The non-availability of climate information can likewise be overcome by utilizing $\mathrm{ET}_{0}$ models with less climate information necessities. Allen et al. (1998) have suggested that when adequate information to apply the FAOPM model is not accessible, the Hargreaves Eqn. is prescribed for estimation of $\mathrm{ET}_{0}$.

According to Allen et al. (1998) that under conditions where the input variables of FAOPM are not available or observed with reasonable accuracy, the use of TPM approach is justified by the possible loss of precision due to parameters estimation, as referred by Allen (1997), these studies are relevant to assess the performance of $\mathrm{ET}_{0}$ calculations when parameters related to a missing variable are replaced by an alternative calculation of the FAOPM equation. Results reported by studies quoted above revealed that the performance of TPM is superior to those obtained when using the HS equation.

Literature suggest that Several studies around the globe under different climate environment (e.g. Liu and Pereira 2001; Pereira et al. 2003; Popova et al. 2006; LópezMoreno et al. 2009) have assessed the accuracy of the TPM equation using only maximum and minimum temperature data by comparing it with results of full data $\mathrm{PMET}_{0}$ and with other $\mathrm{ET}_{0}$ equations, mainly $\mathrm{HS}$ model, and reported that TPM give reliable estimates in accounting $\mathrm{ET}_{0}$ values.

There is various software available to estimate $\mathrm{ET}_{0}$ with the full input information while a few software is available that depends on temperature as fundamental data for processing reference evapotranspiration. DAILYET (Hess, 1999) is a Windows-based program, which could be used to day or month level reference evapotranspiration estimation. However, it requires most of the input data like that standard FAOPM. GSRad (Donatelli et al. 2006a; b) is software to estimate software component containing models to estimate extraterrestrial and ground level solar radiation from alternative methods. Gocic and Trajkovic 2010, developed the software for calculating $\mathrm{ET}_{0}$, feathered for limited weather data environment. Recently, Guo et al. 2016, developed an " $R$ " Package for estimation of different types of evapotranspiration using 17 common methods, but it requires write a programme to estimate $\mathrm{ET}_{0}$ values.

There is no software to best of author's knowledge that estimate all other inputs based on only temperature input. So an attempt is made to develop software that can be easily used under limiting data conditions, only by knowing basic geographical parameters and temperature data.
Microsoft visual basic is a most productive tool for creating high-performance components and applications. It makes use of graphical user interface (GUI) for creating robust and powerful applications. Visual basic features such as easier comprehension, user-friendly, faster application development, etc.

A part of the crucial elements of visual basic 6.0 like make user interface utilizing design instruments, add drawings to structures, set properties for the individual article on the structure, fabricate an executable record, investigate the applications, analyze the items in the structures, work with data in the projects, and add more usefulness to the system by composing code. In the present study, an endeavor is made to gauge reference $\mathrm{ET}_{0}$ in view of TPM method and Hargreaves system by utilizing Visual Basic Environment.

\section{Methodology}

\section{Detail of study area}

The study was conducted for Umaim (Meghalaya), India. The area comes under the temperate, tropical hill zone. The area falls under class VII land, and the soil belongs to regular peadalf series with clay loam texture with $\mathrm{pH}$ varying from 5.4 to 6.2 and is situated an $25^{\circ} 41^{\prime} 21^{\prime \prime} \mathrm{N}$ Latitude, $94^{\circ} 55^{\prime} 25^{\prime \prime} \mathrm{E}$ Longitude and at an altitude of $1010 \mathrm{~m}$ above mean sea level. The study site depicted in Fig. 1.

The daily data were collected for the period of 11 years (January 2000-December 2010) from, ICAR Research Complex at Umaim in Meghalaya (Barapani), India.

\section{Penman-Monteith FAO-56 Model (FAOPM)}

The standard universally accepted FAO-56 PenmanMonteith combination equation (FAOPM) has been recommended by $\mathrm{FAO}$ as the standard equation for estimating $\mathrm{ET}_{0}$ Allen et al. 1998,

$E T_{0}=\frac{0.408 \Delta\left(R_{n}-G\right)+\gamma \frac{900}{T+273} u_{2}\left(e_{S}-e_{a}\right)}{\Delta+\gamma\left(1+0.34 u_{2}\right)}$

where $\mathrm{ET}_{0}$ is the reference evapotranspiration $\left(\mathrm{mm} \mathrm{day}{ }^{-1}\right), \mathrm{R}_{\mathrm{n}}$ the net radiation at the crop surface $\left(\mathrm{MJ} \mathrm{m}^{-2} \mathrm{day}^{-1}\right), \mathrm{G}$ the soil heat flux $\left(\mathrm{MJ} \mathrm{m}^{-2}\right.$ day $\left.^{-1}\right), \mathrm{T}$ the mean air temperature at $2 \mathrm{~m}$ height $\left({ }^{\circ} \mathrm{C}\right), \mathrm{u}_{2}$ the wind speed at $2 \mathrm{~m}$ height $\left(\mathrm{m} \mathrm{s}^{-1}\right), e_{S}$ the saturated vapour pressure $(\mathrm{kPa}), e_{a}$ the actual vapour pressure $(\mathrm{kPa}), e_{S}-$ $e_{a}$ the vapour pressure deficit $(\mathrm{kPa}), \Delta$ the slope vapour pressure curve $\left(\mathrm{kPa}^{\circ} \mathrm{C}^{-1}\right), \gamma$ is the psychometric constant $\left(\mathrm{kPa}{ }^{\circ} \mathrm{C}^{-1}\right)$. 


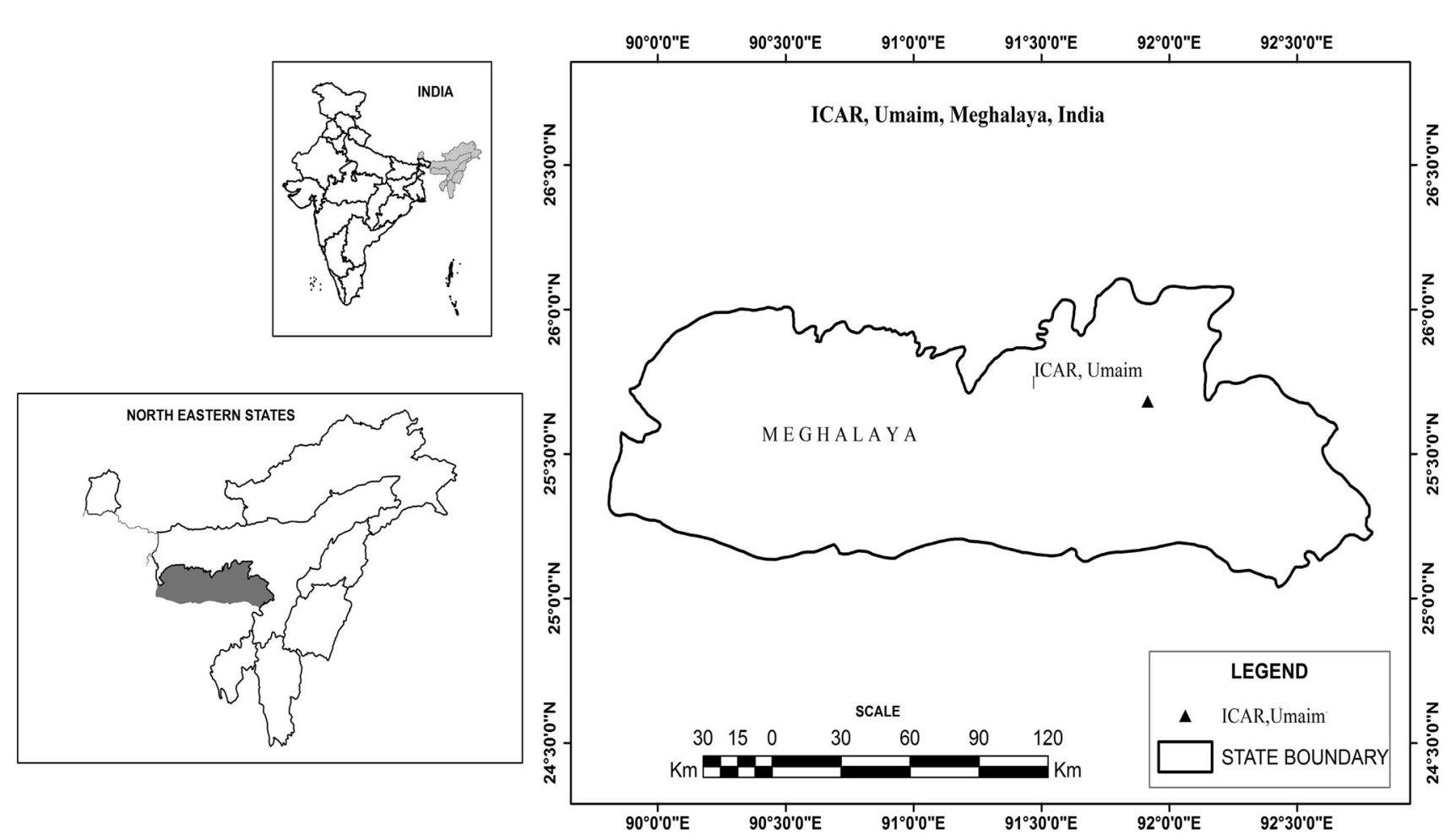

Fig. 1 Location map of study site, showing selected meteorological station

\section{Temperature-based Penman-Monteith model (TPM)}

TPM was utilized to calculate $\mathrm{ET}_{0}$ from the temperature data taking after the proposals of (Allen et al. 1998; Allen 2002; Kra 2010). In the TPM the daily values of $e_{s}, e_{a}, R_{n}$, $\mathrm{G}, \Delta, \gamma$, data and associated intermediate parameters were estimated from maximum, and minimum temperatures $T_{\max }$ and $T_{\min }$, the altitude of the station (z), the latitude of the location $(\varphi)$. The detail of all the inputs parameters of FAOPM and their associated parameters are stated in Table 1.

The accompanying parameters were estimated daily basis from temperature data for a climate station utilizing the following eqs: average temperature, T, using Eq. (14); Slope of the saturation vapour pressure versus temperature curve, $\Delta$, using Eq. (13); latent heat of vapourization of water, $\lambda$, using Eq. (17); Psychometric constant, $\gamma$, using Eq. (15); Actual vapour pressure, $e_{a}$, using Eq. (2); Saturation vapour pressure, $e_{s}$, using Eq. (3); Extraterrestrial radiation, Ra, using Eq. (7); Solar radiation, Rs, using Eq. (6); Clear sky radiation, Rso, using Eq. (12); Net longwave radiation, Rnl, using Eq. (11); Net shortwave radiation, Rns, using Eq. (6); Net radiation, Rn, using Eq. (4); TPM reference grass evapotranspiration, $\mathrm{ET}_{0}$ using Eq. (1). The detail of the formula used for calculations of each eqns. including references depicted in Table 1.

\section{Hargreaves-Samani (HS) method}

The HS eqn. as presented by Hargreaves and Samani (1985), Allen (1997) and Pandey et al. (2009):

$E T_{0}=0.0135(K T)(T+H T)\left(T_{\max }-T_{\min }\right)^{H E} R_{a}$

where $\mathrm{ET}_{0}$ is the reference evapotranspiration in $\mathrm{MJ} \mathrm{m}{ }^{-2}$ day $^{-1}$, KT the empirical coefficient, $\mathrm{T}$ the mean air temperature in ${ }^{\circ} \mathrm{C}$, HT the Hargreaves Temperature Coefficient, $\mathrm{T}_{\max }$ the maximum air temperature in ${ }^{\circ} \mathrm{C}, \mathrm{T}_{\min }$ the minimum air temperature in ${ }^{\circ} \mathrm{C}, \mathrm{HE}$ the Hargreaves's Exponent, $\mathrm{Ra}$ the extraterrestrial radiation in $\mathrm{MJ} \mathrm{m}^{-2}$ day $^{-1}$, HE the 0.5, HT is the 17.8 (Hargreaves 1994).

$\mathrm{ET}_{0}$ is converted to $\mathrm{mm} \mathrm{day}^{-1}$ by a conversion factor of 0.408. According to Hargreaves (1994) the suitable values may be used as $(\mathrm{KT}=0.162$ for "interior" regions and $\mathrm{KT}=0.19$ for coastal regions). Further, Allen (1996), prescribed a condition to figure observational coefficient as $\mathrm{KT}=0.17$ (mean monthly atmospheric pressure of the site $(\mathrm{P}) /$ mean monthly atmospheric pressure at sea level $\left(\mathrm{P}_{0}\right)^{0.5}$ for "interior" sites, and $\mathrm{KT}=0.2(\mathrm{P} / \mathrm{Po})^{0.5}$ for "seaside" locales to suit region to a substantial water body and altitude impact on the volumetric warmth limit of the atmosphere.

\section{Development of software}

A computer program was developed to estimate reference evapotranspiration $\left(\mathrm{ET}_{0}\right)$ based on TPM and HS models in 
Table 1 Details of calculation formula of intermediate parameters of TPM including their references

\begin{tabular}{|c|c|c|c|c|}
\hline Parameters (abbreviation) & Unit & References & Formula & Eq. no. \\
\hline Actual vapor pressure, $\left(e_{a}\right)$ & $\mathrm{kPa}$ & $\begin{array}{l}\text { Allen et al. } \\
\text { (1998) }\end{array}$ & $e_{a}=0.611 \exp \left[\frac{17.27 T_{\min }}{T_{\min }+237.3}\right]$ & 2 \\
\hline $\begin{array}{l}\text { Saturated vapor pressure, } \\
\left(e_{s}\right)\end{array}$ & $\mathrm{kPa}$ & $\begin{array}{l}\text { Allen et al. } \\
\text { (1998) }\end{array}$ & $e_{s}=0.611\left(\exp \left(\frac{17.27 T_{\max }}{T_{\max }+237.3}\right)+\exp \left(\frac{17.27 T_{\min }}{T_{\min }+237.3}\right)\right)$ & 3 \\
\hline Net radiation, $\left(R_{n}\right)$ & MJ m ${ }^{-2}$ day $^{-1}$ & $\begin{array}{l}\text { Allen et al. } \\
\text { (1998) }\end{array}$ & $R_{n}=R_{n s}-R_{n l}$ & 4 \\
\hline Net shortwave radiation, & MJ m ${ }^{-2}$ day $^{-1}$ & $\begin{array}{l}\text { Allen et al. } \\
\text { (1998) }\end{array}$ & $R_{n s}=0.77 R_{s}$ & 5 \\
\hline Solar radiation $\left(R_{s}\right)$ & $\mathrm{MJ} \mathrm{m}^{-2}$ day $^{-1}$ & $\begin{array}{l}\text { Allen et al. } \\
(1998)\end{array}$ & $\begin{array}{l}R_{s}=k_{R_{s}} \cdot R_{a}\left(T_{\max }-T_{\min }\right)^{0.5} \\
\text { where, } k_{R_{S}}=0.16 \text { for other locations (Hargreaves and Allen 2003) }\end{array}$ & 6 \\
\hline $\begin{array}{l}\text { Extraterrestrial radiation } \\
\quad\left(R_{a}\right)\end{array}$ & MJ m ${ }^{-2}$ day $^{-1}$ & $\begin{array}{l}\text { Duffie and } \\
\text { Beckman } \\
(1991)\end{array}$ & $R_{a}=\frac{24 \times 60}{\pi} G_{s c} d_{r}\left[\omega_{s} \sin (\varphi) \sin (\delta)+\cos (\varphi) \sin (\delta)\right]$ & 7 \\
\hline Solar declination $(\delta)$ & radians & Allen (2002) & $\begin{array}{l}\delta=0.4093 \sin \left(\frac{2 \pi(284+J)}{365}\right) \\
\text { where, } J \text { is the Julian day (is the number of the day in the year } \\
\text { between } 1 \text { ( } 1 \text { January) and } 365 \text { or } 366 \text { ( } 31 \text { December) })\end{array}$ & 8 \\
\hline $\begin{array}{l}\text { Relative Earth-sun } \\
\text { distance }\left(d_{r}\right)\end{array}$ & & $\begin{array}{l}\text { Allen et al. } \\
(1998)\end{array}$ & $d_{r}=1+0.033 \cos \left(\frac{2 \pi J}{365}\right)$ & 9 \\
\hline Sunset hour angle $\left(\omega_{s}\right)$ & radians & $\begin{array}{l}\text { Allen et al. } \\
\text { (1998) }\end{array}$ & $\omega_{s}=\cos ^{-1}(-\tan (\varphi) \tan (\delta))$ & 10 \\
\hline $\begin{array}{l}\text { Net long-wave radiation, } \\
R_{n l}\end{array}$ & MJ m ${ }^{-2}$ day $^{-1}$ & $\begin{array}{l}\text { Allen et al. } \\
\text { (1998) }\end{array}$ & $R_{n l}=\sigma \frac{\left(T_{\max }+273.16\right)^{4}+\left(273.16+T_{\min }\right)^{4}}{2}\left(0.34-0.14 \sqrt{e_{a}}\right)\left(\frac{1.35}{R_{s o}}-0.35\right)$ & 11 \\
\hline $\begin{array}{l}\text { Clear sky solar radiation } \\
\quad(R s o)\end{array}$ & MJ m ${ }^{-2}$ day $^{-1}$ & $\begin{array}{l}\text { Allen et al. } \\
\text { (1998) }\end{array}$ & $\begin{array}{l}R_{s o}=\left(0.75+2 \times 10^{-5} z\right) R_{a} \\
\text { where } \mathrm{z}=\text { altitude above sea level }(\mathrm{m})\end{array}$ & 12 \\
\hline $\begin{array}{l}\text { Slope of vapor pressure- } \\
\text { temperature curve }(\Delta)\end{array}$ & $\mathrm{kPa}{ }^{\circ} \mathrm{C}^{-1}$ & $\begin{array}{l}\text { (Murray 1967; } \\
\text { Tetens 1930) }\end{array}$ & $\Delta=\frac{2503 \exp \left(\frac{17277}{T+2373}\right)}{(T+237.3)^{2}}$, where, $\mathrm{T}$ is the mean temperature $\left({ }^{\circ} \mathrm{C}\right)$ & 13 \\
\hline Mean temperature(T) & $\left({ }^{\circ} \mathrm{C}\right)$ & $\begin{array}{l}\text { Allen et al. } \\
\text { (1998) }\end{array}$ & $T=\frac{T_{\max }+T_{\min }}{2}$ & 14 \\
\hline psychrometric constant, $\gamma$ & $\mathrm{kPa}{ }^{\circ} \mathrm{C}^{-1}$ & $\begin{array}{l}\text { Allen et al. } \\
\text { (1998) }\end{array}$ & $\begin{array}{l}\gamma=0.000665 P \\
\text { where, } P \text { is the atmospheric pressure }(\mathrm{kPa})\end{array}$ & 15 \\
\hline $\begin{array}{l}P \text { at elevation, } z \mathrm{~m} \text { above } \\
\text { sea level }\end{array}$ & $(\mathrm{kPa})$ & $\begin{array}{l}\text { Allen et al. } \\
\text { (1998) }\end{array}$ & $P=101.3\left[\frac{293-0.0065 z}{293}\right]^{5.26}$ where $\mathrm{z}$ is the elevation $(\mathrm{m})$ & 16 \\
\hline $\begin{array}{l}\text { Latent heat of vaporization } \\
(\lambda)\end{array}$ & $\mathrm{MJ} \mathrm{kg}^{-1}$ & $\begin{array}{l}\text { Allen et al. } \\
\text { (1998) }\end{array}$ & $\lambda=2.501-\left(2.361 \times 10^{-3}\right) T$ & 17 \\
\hline
\end{tabular}

visual basic 6.0 using Eqs. (1-18) and the process flowchart (Fig. 2) of the program.

\section{Input data}

The essential input data for developed software are the name of station \& location, date $(\mathrm{dd} / \mathrm{mm} / \mathrm{yy})$, daily maximum temperature $\left({ }^{\circ} \mathrm{C}, \mathrm{T}_{\text {max }}\right)$, daily minimum temperature $\left({ }^{\circ} \mathrm{C}, \mathrm{T}_{\text {min }}\right)$, latitude $\left({ }^{\circ}\right.$ or $\left.\mathrm{rad}\right)$, long-term average wind velocity $\left(\mathrm{ms}^{-1}\right)$, and elevation $(\mathrm{m})$. The minimum necessary data for the software are latitude, elevation, temperature, and day or month information for the weather station. A sample screen printout of input parameters as shown in Fig. 3.

\section{Output data}

The desired output parameters are reference evapotranspiration $\left(\mathrm{ET}_{0}\right)$ in $\mathrm{mm} \mathrm{day}^{-1}$ using following methods: temperature-based Penman-Monteith (TPM) and HargreavesSamani (HS) method. A screen printout of sample output parameters as shown in Fig. 4.

\section{Graphical user interface}

The GUI based on a mouse drove approach and provides a connection between data and user. The window of the interface consists of six parts. The window includes information about the weather station (latitude and 
Fig. 2 Process flow chart of model developed for estimation of reference evapotranspiration using TPM and HS equation

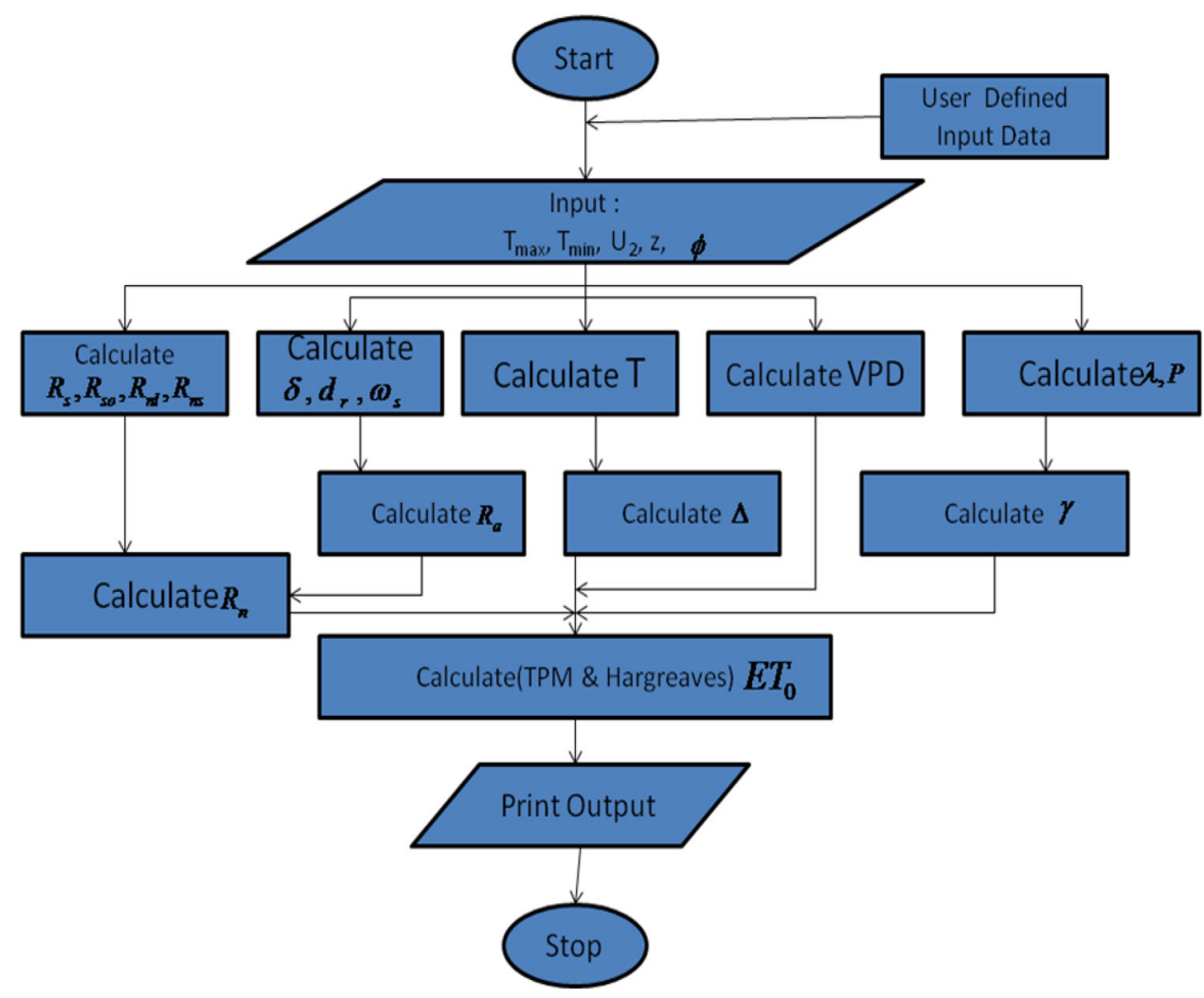

Fig. 3 Input parameters and initial window of developed software

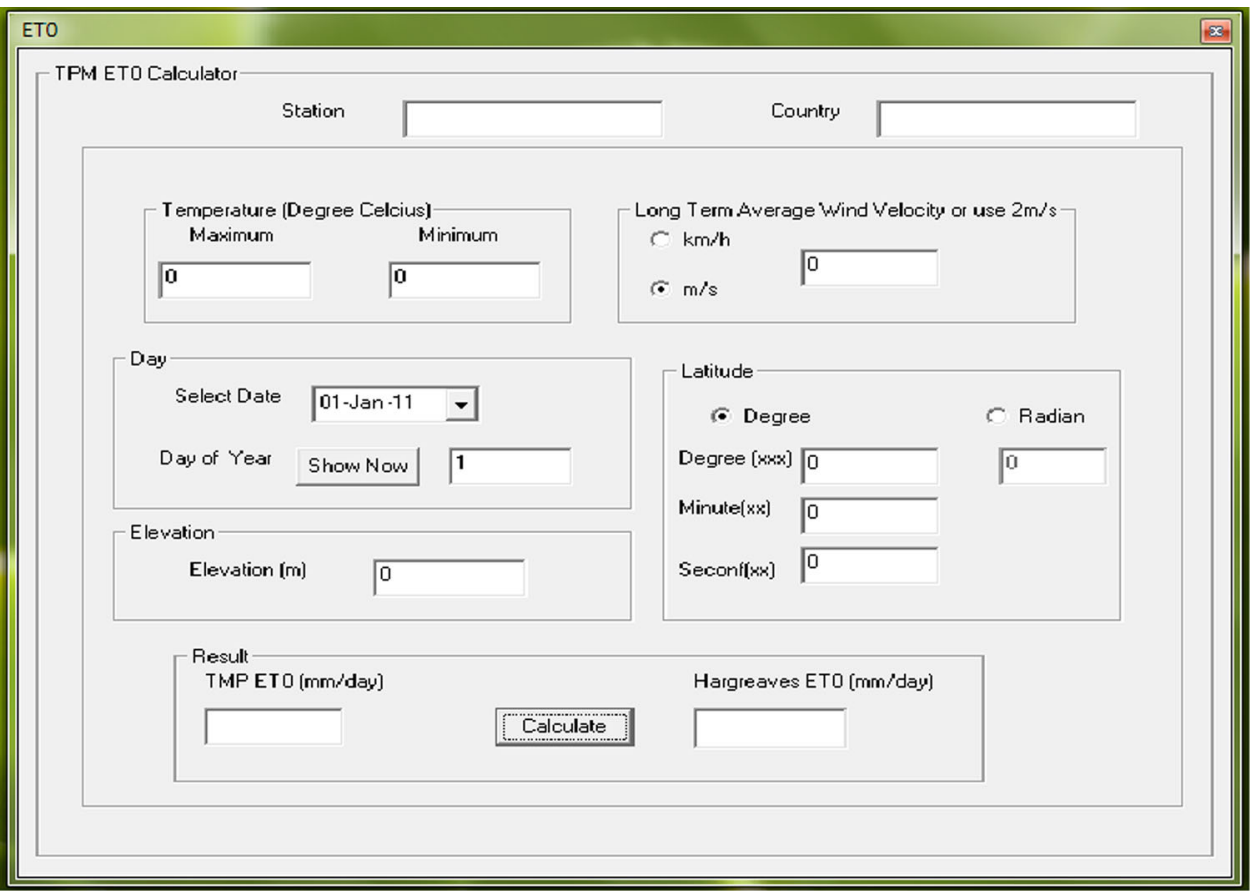

elevation), daily maximum and minimum temperatures, the long-term average wind speed, and date. When the user clicks the command button, the $\mathrm{ET}_{0}$ is calculated by TPM and HS model.
Overview of the developed software

The software developed using visual basic 6.0 environments has a window serving specific purposes in the $\mathrm{ET}_{0}$ 
Fig. 4 Sample output of the developed software

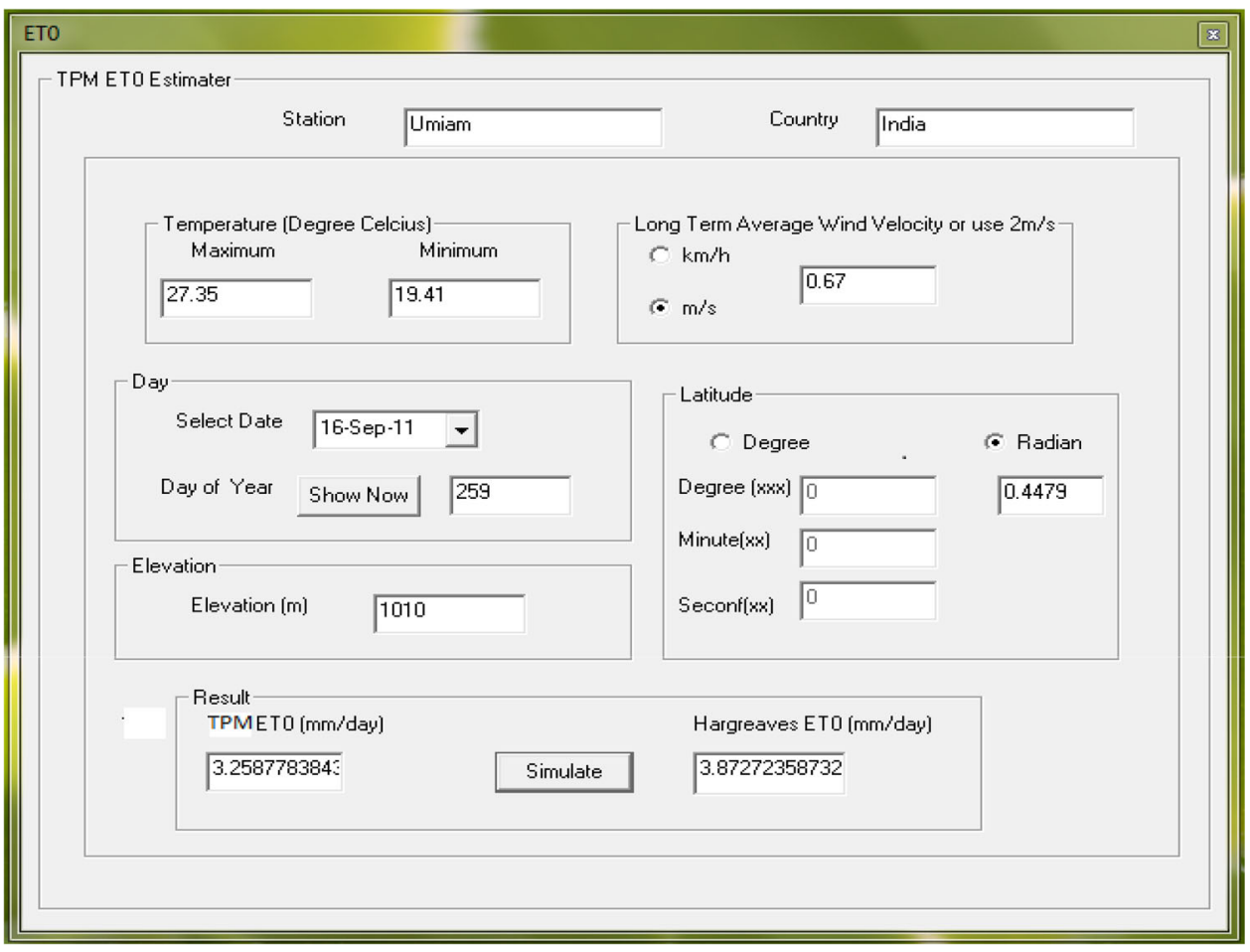

estimation process. The window consists of weather station input parameters, data input parameters, and the result.

\section{Functioning of the software}

The software starts by showing the $\mathrm{ET}_{0}$ estimation window. It contains all the input parameters. The window is designed in such a way that there is a minimum error in entering the data, for example, a user cannot enter decimal twice and cannot input any alphabets in data input box. After the user had entered all the input parameters in their respective text box, he can go to simulate button provided in the bottom portion of window

\section{Simulation of the program}

When all the specification is entered then to obtain the results, the simulated button is to be clicked. In the simulation, all the values of the standard selected are extracted from the windows and used to calculate the required output. When the output values are calculated, they are displayed in the result box.

\section{Statistical approach}

For regression curve fits, the error is assessed using the RMSE, 1:1 line criteria and correlation coefficient. They give a helpful evaluation in compression between two methods. RMSE used as the main parameter for evaluating the reliability of TPM and HS methods in predicting $\mathrm{ET}_{0}$ in comparison with FAOPM at the location. Therefore, RMSE parameter was used to show the goodness-of-fit of $\mathrm{ET}_{0}$ estimates as compared to FAOPM. The RMSE of the estimate is defined as follows:

$R M S E=\sqrt{\left(\frac{\left(\sum_{i=1}^{N} E T_{F A O 56 P M, i}-E T_{E q, i}\right)^{2}}{n}\right)}$

where $E T_{F A O 56 P M, i}$ is the $\mathrm{ET}_{0}$ estimated by standard FAOPM, $E T_{E q}$. the $E T_{0}$ estimated by other selected methods, $\mathrm{n}$ is a total number of observations.

Another measure of goodness-of-fit is the correlation coefficient (r), the slope of the regression and the absolute deviation was also computed. The best fit method is the one with the lowest absolute deviation ' $a$ ' value closest to zero and ' $b$ ' value closest to one and smallest RMSE (Amatya et al. 1995).

\section{Results}

Evapotranspiration can be seen as a combined effect of various climatic parameters. The relationship of evapotranspiration with different climatic factor helps in identification of specific parameter to be used for estimation. In 


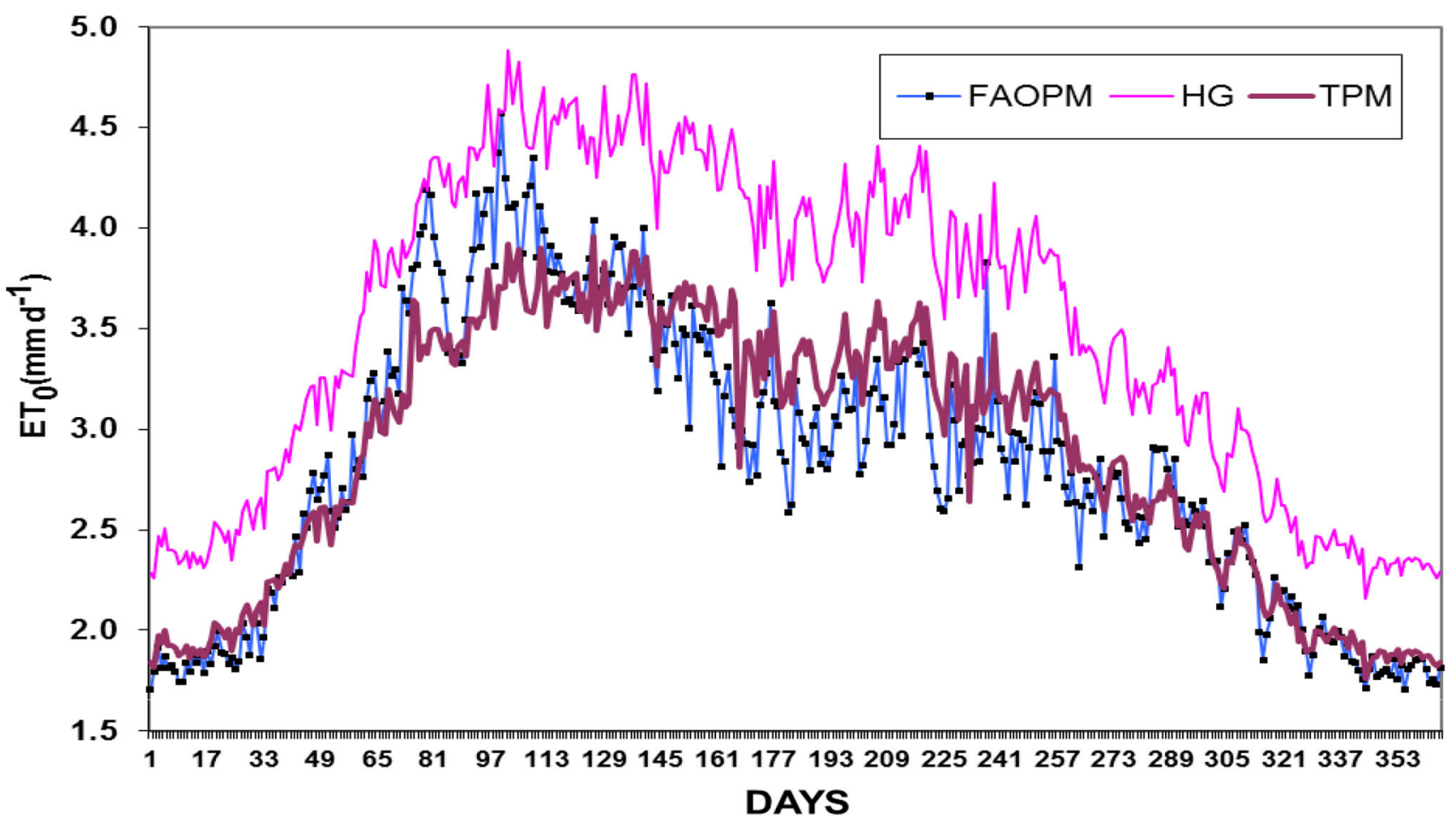

Fig. 5 Variation of reference evapotranspiration $\left(\mathrm{ET}_{0}\right)$ with time using FAOPM, HS, and TPM models

Table 2 Average statistical indices between selected models of $\mathrm{ET}_{0}$ estimation with FAOPM

\begin{tabular}{|c|c|c|c|c|c|c|}
\hline \multicolumn{2}{|l|}{ Methods } & \multicolumn{2}{|c|}{ Values of the constants of the equation $(\mathrm{Y}=\mathrm{a}+\mathrm{bX})$} & \multirow{2}{*}{$\begin{array}{l}\text { Root mean square error, } \\
\text { RMSE }\left(\mathrm{mm} \mathrm{day}^{-1}\right)\end{array}$} & \multirow{2}{*}{$\begin{array}{l}\text { Correlation } \\
\text { coefficient, } \mathrm{r}^{*}\end{array}$} & \multirow{2}{*}{$\begin{array}{l}\text { Average } \\
\text { overestimation }\end{array}$} \\
\hline $\mathrm{X}$ & $\mathrm{Y}$ & $\mathrm{a}$ & $\mathrm{b}$ & & & \\
\hline FAOPM & TPM & 0.8664 & 0.4297 & 0.014 & 0.92 & +1.75 \\
\hline FAOPM & HS & 1.042 & 0.5772 & 0.054 & 0.87 & +19.74 \\
\hline
\end{tabular}

* Significant at $1 \%$ level

the present study, an attempt is made to check the validity of temperature-based approach for estimation of $\mathrm{ET}_{0}$.

\section{Output of developed software}

The developed software can be suitably used to estimate reference evapotranspiration under poor data condition when sufficient data to solve FAOPM are not available. When the required input parameters $\left(\mathrm{T}_{\max }, \mathrm{T}_{\min }\right.$, and $\left.\mathrm{U}_{2}\right)$ and weather station information are entered, then to obtain the results the simulated button is to be clicked. In the simulation, all the values of the specifications selected are extracted from the windows and used to calculate the required output. When the output values are calculated, they are displayed in the result box. A sample result screen printout of the $\mathrm{ET}_{0}$ applications is shown in Fig. 4.

\section{Comparison and inter-relationships among various ET o models}

The daily reference evapotranspiration values obtained from different reference evapotranspiration models for Umaim are shown in Fig. 5 and Table 2. There is a strong deviation between the reference evapotranspiration values obtained from different methods.

\section{Penman-Monteith FAO-56 model (FAOPM)}

It is worth mentioning that FAO has recommended universal use of FAO56 Penman-Monteith method (FAOPM) (Allen et al. 1998). The estimated daily values of reference evapotranspiration computed by Penman-Monteith FAO56 method are presented in Table 2. It was observed that 
Fig. 6 Comparison between the estimated $\mathrm{ET}_{0}$ by TPM and FAOPM model

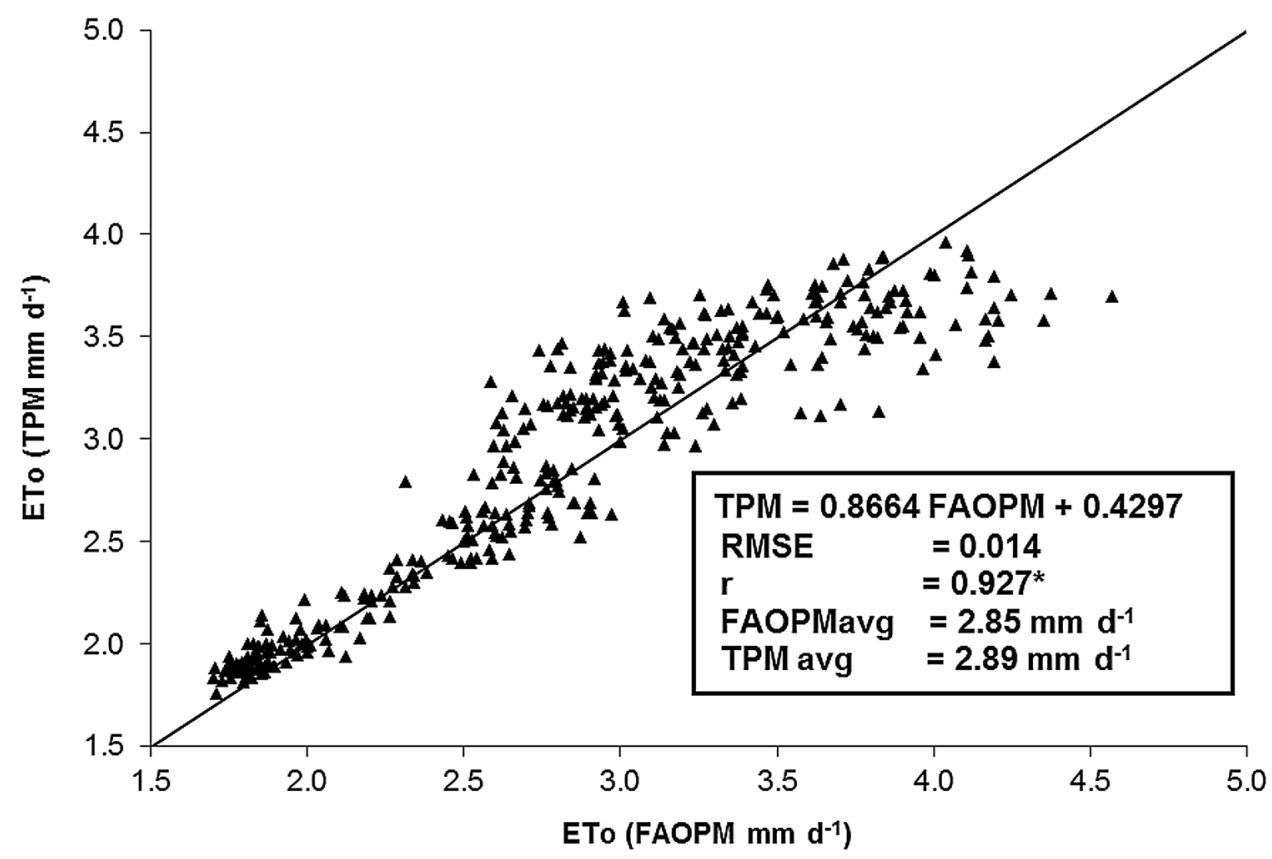

the lowest value of reference evapotranspiration $\left(1.70 \mathrm{~mm} \mathrm{day}^{-1}\right)$ occurred in day number 1 and 355 , and the highest value of reference evapotranspiration $(4.57 \mathrm{~mm}$ per day) took place in day's number 100 . The average daily reference evapotranspiration value obtained for Umaim was observed to $2.85 \mathrm{~mm}_{\text {day }}{ }^{-1}$.

\section{Temperature Penman-Monteith model (TPM)}

The estimated daily values of reference evapotranspiration computed by TPM method are presented in Fig. 5. It was observed that the lowest value of reference evapotranspiration $\left(2.56 \mathrm{~mm} \mathrm{day}^{-1}\right)$ occurred in day number 350 , and the highest value of reference evapotranspiration (4.08 $\mathrm{mm} \mathrm{day}{ }^{-1}$ ) took place in day number 80 . The average daily reference evapotranspiration value obtained from TPM model for Umaim (Barapani) was observed to be $3.26 \mathrm{~mm}$ per day. The lowest daily mean temperature $\left(11.7^{\circ} \mathrm{C}\right)$ and the highest daily mean temperature $\left(24.84{ }^{\circ} \mathrm{C}\right)$ were recorded in day numbers 25 and 216, respectively. Therefore, the lowest value of reference evapotranspiration and the highest value of reference evapotranspiration were observed to be in day numbers 350 and 80 , respectively. A comparison was made between $\mathrm{ET}_{0}$ estimated by TPM model and FAO PM model. The relationship is depicted in Fig. 5 which show that there exists a linear relationship between and TPM model and FAOPM model with RMSE $=0.014 \mathrm{~mm} \mathrm{day}^{-1}$, and $\mathrm{r}=0.927$, which is significant at $1 \%$ level (Table 1 ). TPM model overestimated the standard FAO PM by $1.75 \%$ at the site (Fig. 6).

\section{Hargreaves-Samani (HS) method}

It was observed that the lowest value of reference evapotranspiration $\left(3.23 \mathrm{~mm} \mathrm{day}^{-1}\right.$ ) occurred in day's number 177 , and the highest value of reference evapotranspiration $\left(4.61 \mathrm{~mm} \mathrm{day}^{-1}\right)$ took place in day number 102 . The average daily reference evapotranspiration value obtained from HS model over Umaim was observed to be $3.82 \mathrm{~mm} \mathrm{day}^{-1}$. A comparative study shows that there exists a linear relationship between HS model and FAOPM model with RMSE $=0.054 \mathrm{~mm} \mathrm{day}^{-1}$, and the $\mathrm{r}=0.87$, which is significant at $1 \%$ level (Table 2). The relationship is depicted in Fig. 7. Hargreaves method overestimates the standard FAOPM by $19.74 \%$. From Table 2 it is clear that TPM method is related more closely to FAOPM method in comparison to HS method with the value of ' $r$ ' as 0.92 followed by Hargreaves's with ' $r$ ' value of 0.87 .

\section{Discussion and conclusions}

There is an advantage of using TPM approach compared to combination equations, which is regularly neglected, that is the fewer data necessity since just extreme air temperatures are required. This is imperative in areas where solar radiation, humidity, and wind speed information are missing or are of low or faulty quality. Truth be told, air temperature can be measured with less fault and by less skilled people than the other atmosphere variables required by FAO56PM. 
Fig. 7 Comparison between the estimated $\mathrm{ET}_{0}$ by HARG and FAOPM model

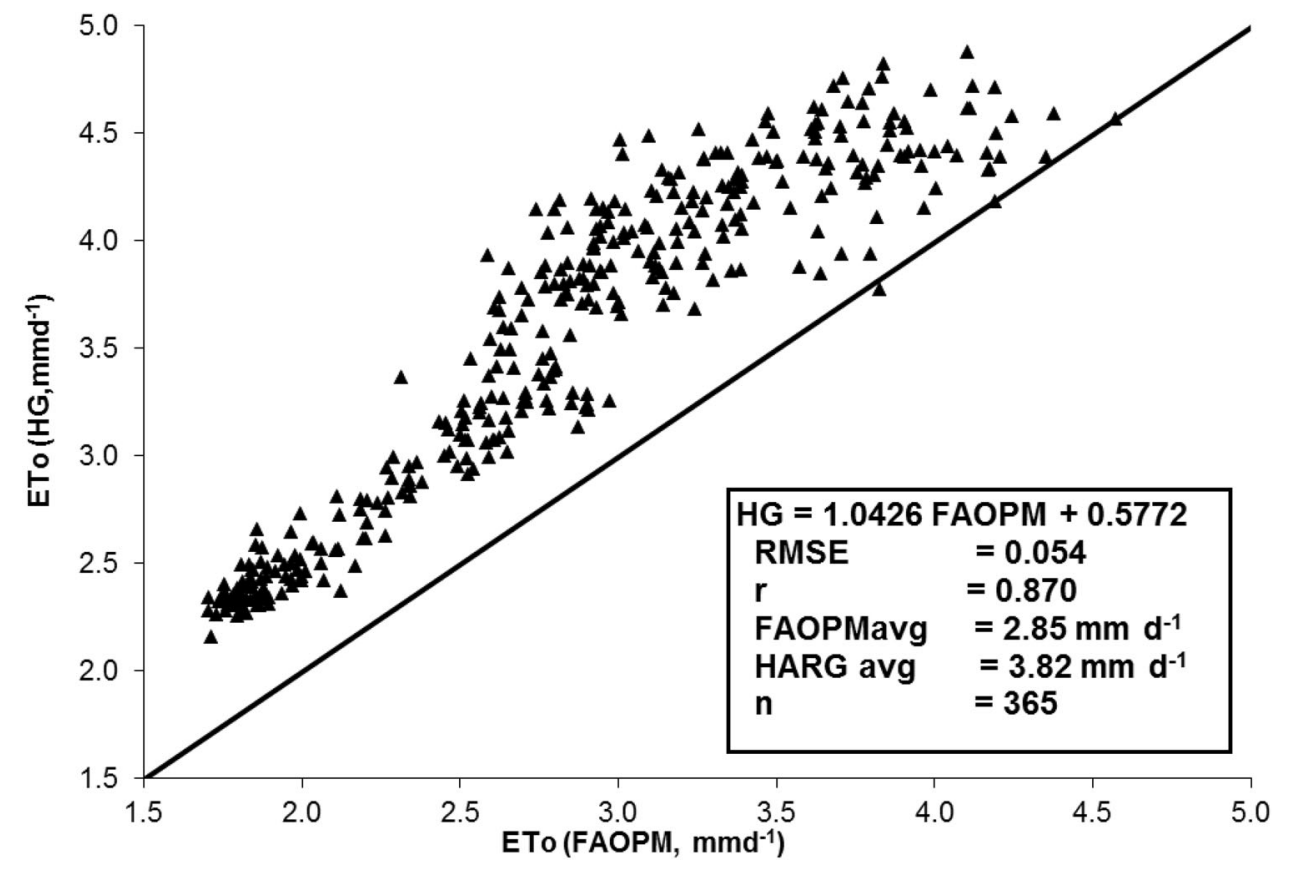

In this study, the software for estimating reference evapotranspiration using only temperature weather data has been presented. It is based on FAO reduced data set methodology for estimating reference evapotranspiration and a user-friendly software based on two limited data approach (e.g. TPM, and HS model), and provides estimates of daily/monthly $\mathrm{ET}_{0}$ values. The developed software may a suitable alternative of FAOPM under nonavailability of inputs data such as solar radiation, wind speed, relative humidity. All the selected temperaturebased models; TPM, and HS overestimated the FAO PM values. The average daily $\mathrm{ET}_{0}$ value obtained by the TPM is $2.89 \mathrm{~mm} \mathrm{day}^{-1}$, which is close to the mean daily $\mathrm{ET}_{0}$ value $\left(2.85 \mathrm{~mm} \mathrm{day}^{-1}\right)$ obtained from the FAOPM method. Based on the regression analysis the alternative methods to the FAO56 Penman-Monteith, for estimation of reference evapotranspiration, is TPM, HS, methods in order of superiority for Umaim.

According to Allen 1996 and Hargreaves and Allen 2003 the limit of deviation (i.e. $15 \%$ ) for calibrated models against FAO56PM. In the study suggested TPM model overestimated $1.75 \%$ is well within the suggested limit under humid environment. The overall deviation of FAO suggested HS model was +19.74 are too high over the recommended limit. Similar finding reported by $\mathrm{Lu}$ et al. 2005 on evaluation of HS equation in Sothern eastern US. However, the deviation in the arid region was not tested, but the author may say TPM will perform equally well in arid or semi-arid regions also. In another study in North and Central Tunisia by (Jabloun and Sahli 2008) reported similar results that HS equation overestimated $\mathrm{ET}_{0}$ whereas the TMP method produced better estimates.

Findings of present study leads to conclude that the HS has larger overestimation compared to TPM against standard FAOPM, is well correlated with other reported studies in humid environment (e.g. Yoder et al. 2005; Martinez and Thepadia 2010; Tabari 2010; Todorovic et al.2013). The developed software could be successfully used to estimate reference evapotranspiration under the limiting data conditions when the use of FAOPM is limited due to nonavailability of required meteorological data.

\section{References}

Allen RG (1996) Assessing integrity of weather data for use in reference evapotranspiration estimation. J Irrig Drain Eng 122(2):97-106

Allen RG (1997) Self-calibrating method for estimating solar radiation from air temperature. J Hydrol Eng 2(2):56-67

Allen R (2002) REF-ET: reference evapotranspiration calculation software for FAO and ASCE standardized equations. The University of Idaho. http://www.kimberly.uidaho.edu/ref-et/

Allen RG, Pereira LS, Raes D, Smith M (1998) Crop evapotranspiration: guidelines for computing crop water requirements. FAO irrigation and drainage paper no. 56. FAO, Rome

Amatya DM, Skaggs RW, Gregory JD (1995) Comparison of methods for estimating REF-ET. J Irrig Drain Eng 121:427-435

ASCE-EWRI (2005) The ASCE standardized reference evapotranspiration equation. In: Allen RG, Walter IA, Elliot RL et al (eds) Environmental and Water Resources Institute (EWRI) of the American Society of Civil Engineers, ASCE, Standardization of Reference Evapotranspiration Task Committee final report. American Society of Civil Engineers (ASCE), Reston 
Donatelli M, Bellocchi G, Carlini L (2006a) A software component for estimating solar radiation. Environ Model Softw 21(3):411-416

Donatelli M, Bellocchi G, Carlini L (2006b) Sharing knowledge via software components: models on reference evapotranspiration. Eur J Agron 24(2):186-192

Droogers P, Allen RG (2002) Estimating reference evapotranspiration under inaccurate data conditions. Irrig Drain Syst 16:33-45

Duffie JA, Beckman WA (1991) Solar engineering of thermal processes, 2nd edn. Wiley, New York

Gocic M, Trajkovic S (2010) Software for estimating reference evapotranspiration using limited weather data computer and electronics. Agriculture 71:158-162

Guo D, Westra S, Maier HR (2016) An R package for modelling actual, potential and reference evapotranspiration. Environ Model Softw 78:216-224. doi:10.1016/j.envsoft.2015.12.019

Hargreaves GH (1994) Defining and using reference evapotranspiration. J Irrig Drain Eng 120(6):1132-1139

Hargreaves GH, Allen RG (2003) History and evaluation of Hargreaves evapotranspiration equation. J Irrig Drain Eng 129(1):53-63

Hargreaves GH, Samani ZA (1985) Reference crop evapotranspiration from temperature. Appl Eng Agric 1(2):96-99

Hess T (1999) Potential evapotranspiration programme for automatic weather stations. Version 3. Cranfield University Silsoe, Bedford

Jabloun M, Sahli A (2008) Evaluation of FAO-56 methodology for estimating reference Evapotranspiration using limited climatic data application to Tunisia. Agric Water Manage 95:707-715

Jensen ME, Burman RD, Allen RG (1990) Evapotranspiration and irrigation water requirements. ASCE manuals and reports on engineering practices no. 70. Am. Soc. Civil Engrs., New York, pp 60

Kra EY (2010) An empirical simplification of the temperature Penman-Monteith model for the tropics. J Agric Sci 2(1):162-171

Liu Y, Pereira LS (2001) Calculation methods for reference evapotranspiration with limited weather data (in Chinese). J Hydraul 3:11-17

López-Moreno JI, Hess TM, White SM (2009) Estimation of reference evapotranspiration in a mountainous Mediterranean site using the Penman-Monteith equation with limited meteorological data. Pirineos 164:7-31

Lu JB, Sun G, Mcnolty SG, Amatya DM (2005) A comparison of six potential evapotranspiration methods for regional use in the southeastern United States. J Am Water Resour Assoc 41:621-633

Martinez CJ, Thepadia M (2010) Estimating reference evapotranspiration with minimum data in Florida. J Irrig Drain Eng 136(7):494-501

Murray FW (1967) On the computation of saturation vapor pressure. J Appl Meteor 6:203-204

Pandey PK, Pandey V (2011) Lysimeter based crop coefficients for estimation of crop evapotranspiration of black gram (Vigna Mungo L.) in sub-humid region. Int J Agric Biol Eng 4(4):50-58. doi:10.3965/j.issn.1934-6344.2011.04.050-058

Pandey PK, Radheshyam K, Hibu C (2009) Assessing the performance of temperature based evapotranspiration models under the climatic conditions of Umaim (Meghalaya) India. Zeitschrift für Bewässerungswirtschaft 44(1):57-69

Pandey V, Pandey PK, Mahanta AP (2014) Calibration and performance verification of Hargreaves-Samani equation in a humid region. Irrig Drain 63:659-667

Pandey PK, Dabral PP, Pandey V (2016) Evaluation of reference evapotranspiration methods for the northeastern region of India. Int Soil Water Conserv Res. doi:10.1016/j.iswcr.2016.02.003

Pereira LS, Cai LG, Hann MJ (2003) Farm water and soil management for improved water use in the North China Plain. Irrig Drain 52(4):299-317

Popova Z, Kercheva M, Pereira LS (2006) Validation of the FAO methodology for computing $\mathrm{ET}_{0}$ with limited data. Appl South Bulgaria Irrig Drain 55:201-215

Tabari H (2010) Evaluation of reference crop evapotranspiration equations in various climates Water Resour. Manage 24(10):2311-2337

Tetens O (1930) Ubereinige meteorologische Begriffe. Z Geophys 6:297-309

Todorovic M, Karic B, Pereira LS (2013) Reference evapotranspiration estimate with limited weather data across a range of Mediterranean climates. J Hydrol 481:166-176

Xu CY, Singh VP (2002) Cross comparison of empirical equations for calculating potential evapotranspiration with data from Switzerland. Water Resour Manage 16:197-219

Yoder RE, Odhiambo LO, Wright WC (2005) Evaluation of methods for estimating daily reference crop evapotranspiration at a site in the humid southeast United States. Appl Eng Agric 21(2):197-202 